\title{
Lessons on the Congo Basin
}

\section{Mary F. Kirchwey}

To cite this article: Mary F. Kirchwey (1910) Lessons on the Congo Basin, Journal of Geography, 8:10, 223-224, DOI: 10.1080/00221341008986231

To link to this article: http://dx.doi.org/10.1080/00221341008986231

$$
\text { Published online: } 20 \text { May } 2008 .
$$

Submit your article to this journal

LIII Article views: 3

Q View related articles $\asymp$ 


\title{
LESSONS ON THE CONGO BASIN
}

\author{
By Mary F. Kirchwey
}

\section{Horace Mann School, New York City}

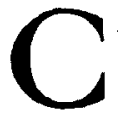

ALL attention to the fact that the history and geography of Northern Africa were well known to Europeans long before the discovery of America, but that Central Africa remained an unknown region, and was so marked on maps, until a few years ago.

Who laid open this region to the world?

Who was Stanley?

How came an American to undertake this task?

(Here follows a brief sketch of Stanley's life as a young man, his position as reporter on the New York Herald, his mission to Africa as war correspondent, his finding of Livingston, and finally his interest in African exploration.)

Let us follow on the map Stanley's journey from the headwaters. of the Congo to its mouth. It has been called an expedition of "unparalleled dangers and difficulties."

Let us try to find out what these great dangers and difficulties were.

(This is the class problem.)

What is the first thing of importance for us to know about the region?

Ans.-What kind of climate it has.

Have you any ideas as to what the climate is like?

Ans.-The Congo is near the equator so it must be very hot there.

Ars.-It is in the Doldrum belt so the rainfall must be heavy.

(Verify these conclusions by referring to the isothermal and rainfall maps. Compare temperature and rainfall with our own.)

What do you think about the healthfulness of a region that is so hot and damp?

Would you then say that the climate was favorable or unfavorable to Stanley's expedition?

There were no roads or paths in the region-how do you suppose Stanley traveled?

(Row-boats bought of the natives.) 
Could he travel by night?

What kind of camping-ground do you suppose he found?

Ans.-Swamps-jungles-haunts of wild animals-villages of savage tribes.

As you follow the river you will find many rapids. Stanley had, at such places, to leave the river and travel for miles through the jungle.

What is the African jungle like?

(Show pictures and read selections from Stanley's "In Darkest Africa" to give jdea of jungle-the swamps and marshes, the dense undergrowth, the darkness-and of the tremendous task it was to clear a path through it.)

What other dangers and difficulties beset his path?

Ans.-There are many wild animals in the region.

Ans.-There are poisonous snakes in the jungle, and poisonous insects.

Ans.-There are many savage tribes.

(Read Paul Du Chaillu's account of the gorilla and other animals of this region, and Stanley's description of the Pygmies and other savage tribes.)

Now let us mention once more the dangers and difficulties that Stanley encountered. (Summary.)

Ans.-Extreme heat-excessive rainfall-unhealthy climategreat swamps, lack of roads-falls and rapids-dense forestshostile tribes-wild animals-poisonous insects.

What was accomplished by Stanley's expedition?

Ans.-An unknown region was made known to the world.

Was this worth all the hardships Stanley endured?

Develop by questions and suggestions the following facts:

Europeans went into the country as soon as Stanley made known its resources and through their influence much has been done-

I. To stop the slave trade of the region.

2. To prevent cannibalism and to improve the condition of the natives generally.

3. To open up the resources of the forests-the valuable rosewood, mahogany, ebony, \&c., and the rubber, gums, and dyewoods.

4. To establish communication with the outside world by means of roads, railroads, steamship lines, \&c. 